\title{
Research on the Selection Model of Medium and Long-term Incentive Modes for State-controlled Listed Companies
}

\author{
Wang $\operatorname{Han}^{1}, \mathrm{Xu}$ Yunfei ${ }^{1}$ \\ ${ }^{1}$ State Grid Energy Research Institute Co.,Ltd., Beijing, China
}

\begin{abstract}
With the continuous improvement of the governance mechanism of state-controlled listed companies, more and more companies are beginning to try to transform them into medium and long-term incentives to stimulate the vitality of talents. This section compares and analyzes the medium and longterm incentive methods applicable to state-controlled listed companies, and summarizes the characteristics, advantages and disadvantages of different incentive methods. It provides an effective reference for conventional holding listed companies to choose an incentive method suitable for company development and employee needs.
\end{abstract}

\section{INTRODUCTION}

Motivation is the core measure of employee management. It is to make employees' interests related to the interests of the company and stimulate their initiative and enthusiasm. Motivation is not only reflected in material satisfaction, but also in the promotion of employee motivation and behavior. Moreover, the means of motivation are mainly to stimulate employees' passion and dedication in a certain event or goal, and strive to give full play to their potential and value. How to influence the psychology and motivation of the motivated object to stimulate their good work attitude and behavior is an important issue that needs to be explained in the motivation research. [1]

Corporate incentives are generally divided into shortterm incentives and long-term incentives. Short-term incentives are mainly reflected in salary, benefits, sales commissions, monthly rewards, quarterly rewards, social security provident fund, etc. It is the benefit income that can be realized and realized in the short term, and it is generally mainly related to the value embodied in the individual or its management and responsibilities. Medium- and long-term incentives are generally related to the company's strategic development direction and interests. The main incentive targets are generally corporate executives or key technical personnel and other core personnel.

With the development and progress of enterprises, the use of short-term incentive measures is far from guaranteeing and promoting the long-term development of enterprises. Enterprises need to take effective measures to tie the interests of employees closely to the interests and development of the enterprise in order to truly benefit the development and long-term planning of the enterprise. Therefore, the implementation of mid- and long-term incentives is of great practical significance for enterprise development.

\section{Selection Model of Medium and Long- TERM INCENTIVE METHODS FOR STATE- CONTROLLED LISTED COMPANIES}

\section{A. Medium and Long-term Incentive Methods and Characteristics of State-controlled Listed Companies}

The medium and long-term incentive methods commonly used by state-controlled listed companies include stock options, restricted stocks and stock appreciation rights. These three methods all have certain differences in the rights acquired, costs, and risks of the incentive objects. Each enterprise should select an incentive method that suits the current development needs of the enterprise based on a comprehensive evaluation of the company's strength, combined with its own development needs and incentive purposes.[2]

TABLE I. COMMONLY USED MEDIUM AND LONG-TERM INCENTIVE METHODS AND CHARACTERISTICS OF STATE-CONTROLLED LISTED COMPANIES

\begin{tabular}{|c|c|c|c|c|}
\hline method & definition & Features & Advantage & Disadvantage \\
\hline stock option & $\begin{array}{l}\text { The listed company grants } \\
\text { incentive objects the right } \\
\text { to purchase a certain } \\
\text { number of shares of the } \\
\text { company within a certain } \\
\text { period of time at the } \\
\text { agreed price and }\end{array}$ & $\begin{array}{l}\text { The incentive object is } \\
\text { granted rights rather } \\
\text { than stocks, and } \\
\text { incentive objects have } \\
\text { the right to exercise this } \\
\text { right, or they can give } \\
\text { up this right. }\end{array}$ & $\begin{array}{l}\text { After the expiration of } \\
\text { the exercise period, the } \\
\text { motivated objects can } \\
\text { freely choose whether } \\
\text { to exercise their rights. } \\
\text { They can choose to } \\
\text { exercise their rights }\end{array}$ & $\begin{array}{l}\text { The lack of restraint on } \\
\text { the incentive objects } \\
\text { makes it difficult to } \\
\text { motivate employees. }\end{array}$ \\
\hline
\end{tabular}




\begin{tabular}{|c|c|c|c|c|}
\hline method & definition & Features & Advantage & Disadvantage \\
\hline & conditions. & & $\begin{array}{l}\text { when the stock price } \\
\text { rises and waive their } \\
\text { rights when the stock } \\
\text { price falls without any } \\
\text { loss. }\end{array}$ & \\
\hline restricted stock & $\begin{array}{l}\text { Incentives are granted a } \\
\text { certain number of shares } \\
\text { of the company according } \\
\text { to predetermined } \\
\text { conditions, and only when } \\
\text { the predetermined } \\
\text { conditions (usually } \\
\text { working life or } \\
\text { performance goals) are } \\
\text { met, the incentives can } \\
\text { sell restricted stocks and } \\
\text { profit from them. }\end{array}$ & $\begin{array}{l}\text { 1. Pay more attention to } \\
\text { the company's long- } \\
\text { term development and } \\
\text { long-term strategic } \\
\text { goals; } \\
2 \text {. Although the } \\
\text { incentive object cannot } \\
\text { sell the stock } \\
\text { immediately, it actually } \\
\text { owns the ownership of } \\
\text { the stock and } \\
\text { shareholder rights. }\end{array}$ & $\begin{array}{l}\text { Closely link the benefits } \\
\text { of incentive objects } \\
\text { with the company's } \\
\text { development, and } \\
\text { encourage incentive } \\
\text { objects to pay more } \\
\text { attention to the } \\
\text { company's long-term } \\
\text { interests. }\end{array}$ & $\begin{array}{l}\text { 1. The company's cash } \\
\text { flow pressure is high; } \\
2 . \text { It is difficult to } \\
\text { guarantee the } \\
\text { scientificity and } \\
\text { rationality of } \\
\text { performance targets. }\end{array}$ \\
\hline $\begin{array}{l}\text { stock } \\
\text { appreciation } \\
\text { rights }\end{array}$ & $\begin{array}{l}\text { Incentives are granted the } \\
\text { right to gain benefits from } \\
\text { stock price rises or } \\
\text { performance } \\
\text { improvements in a certain } \\
\text { period of time in the } \\
\text { future and under agreed } \\
\text { conditions, but they do not } \\
\text { own the ownership of the } \\
\text { stocks. }\end{array}$ & $\begin{array}{l}\text { Only enjoy the benefits } \\
\text { of stock price or } \\
\text { performance } \\
\text { improvement, not the } \\
\text { shareholders' rights. }\end{array}$ & $\begin{array}{l}\text { 1. The operation is } \\
\text { simple and does not } \\
\text { involve equity changes; } \\
\text { 2. The incentive object } \\
\text { does not need to spend } \\
\text { cash; } \\
\text { 3. The incentive object } \\
\text { does not enjoy } \\
\text { shareholder rights. }\end{array}$ & $\begin{array}{l}\text { 1. The stock price and } \\
\text { the company's } \\
\text { performance are } \\
\text { sometimes not } \\
\text { completely correlated, } \\
\text { and the appreciation of } \\
\text { the stock price is used } \\
\text { to determine the } \\
\text { income of the incentive } \\
\text { object, and sometimes } \\
\text { it cannot really achieve } \\
\text { the incentive effect of } \\
\text { improving } \\
\text { company's the } \\
\text { performance; } \\
\text { 2. The cash payment } \\
\text { pressure of enterprises } \\
\text { is greater. }\end{array}$ \\
\hline
\end{tabular}

\section{B. Selection Model of Medium and Long-term Incentive Methods for State-controlled Listed Companies}

Compared with the medium and long-term incentives of state-owned technology enterprises, relevant policies impose fewer restrictions on the medium and long-term incentives of state-owned listed companies, and the requirements are more relaxed, and there are no clear restrictions on the conditions for companies that can implement equity incentives.[3] Therefore, when a statecontrolled listed company chooses an incentive method, the main factors that need to be considered are factors related to the company's own development and incentive goals, such as the company's development stage, competitive strategy, and incentive targets.[4]

\section{1) Clarify the Development Stage of the Company}

According to the theory of enterprise life cycle, the development of an enterprise is generally divided into a start-up period, a growth period, a stable period and a recession period. Companies at different stages have their own characteristics in terms of scale, operating income and product market, and their capital requirements are also different.

TABLE II. CHARACTERISTICS OF EACH STAGE OF THE ENTERPRISE LIFE CYCLE

\begin{tabular}{|c|c|c|}
\hline Life cycle & Features & Capital element \\
\hline \multirow{5}{*}{ early period } & $\begin{array}{c}\text { The production scale is small, the product } \\
\text { market share is low, the fixed cost is large, } \\
\text { the corporate organizational structure is } \\
\text { simple, the production operator and the } \\
\text { manager are integrated, the profitability is } \\
\text { low, the cash flow is not smooth, and } \\
\text { financial difficulties are often encountered. }\end{array}$ & $\begin{array}{c}\text { Capital mainly comes from } \\
\text { entrepreneurs and venture capitalists. }\end{array}$ \\
\hline growth period & $\begin{array}{c}\text { Basically formed its own unique product } \\
\text { series, the product market share has steadily } \\
\text { increased, the market competitiveness has } \\
\text { gradually increased, the business } \\
\text { management model has been gradually } \\
\text { improved, and the performance growth rate } \\
\text { has accelerated. }\end{array}$ & $\begin{array}{c}\text { Use banks for indirect financing, or } \\
\text { financing through the issuance of stocks } \\
\text { and bonds. }\end{array}$ \\
\hline stable period & $\begin{array}{c}\text { The company has strong capital, advanced } \\
\text { technology, rich human resources, improved } \\
\text { management, and strong survivability and } \\
\text { competitiveness. Enterprises can effectively } \\
\text { coordinate daily business processes and } \\
\text { effectively allocate resources. }\end{array}$ & $\begin{array}{c}\text { Diversified financing channels, smooth } \\
\text { cash flow, reasonable asset structure, } \\
\text { and sound capital structure policy. }\end{array}$ \\
\hline Recession period & $\begin{array}{c}\text { The market share of enterprise products is } \\
\text { gradually decreasing, the trial production of } \\
\text { new products has failed, or has not been fully } \\
\text { accepted by the market, and problems have }\end{array}$ & $\begin{array}{c}\text { Stock prices have begun to fall, bank } \\
\text { credit loans have tightened, and } \\
\text { corporate financing capabilities have } \\
\text { declined. }\end{array}$ \\
\hline
\end{tabular}




\begin{tabular}{|c|c|c|}
\hline Life cycle & Features & Capital element \\
\hline & $\begin{array}{c}\text { occurred between management and } \\
\text { departments. }\end{array}$ & \\
\hline
\end{tabular}

Combining the advantages and disadvantages of various equity incentive methods and the characteristics of each development stage of the enterprise, the medium and long-term incentive methods adapted to enterprises in different development stages are also different.

In the initial stage of a company, the company itself lacks strength and has less cash flow, and its management model tends to be more of a joint venture between the company's boss and its employees, rather than a complete principal-agent relationship.[5] The company's incentive strategy should be to guide employees to pay attention to the long-term development of the company and to participate in decision-making appropriately, while minimizing cash flow expenditures. Therefore, it is more appropriate to choose stock options and restricted stocks at this stage.

In the growth period of the company, the company is in a stage of rapid expansion, and there is a large demand for funds, and it is necessary to greatly mobilize the enthusiasm of employees to work hard for the company. Therefore, in this period, it is not appropriate to adopt methods that require high cash flow and have an excessively long incentive cashing cycle. In comparison, stock options are more suitable for growth companies.[6]

During the stable period of the company, the company has entered a relatively long-term and smooth development phase. The company has a good operating and management foundation, relatively sufficient cash flow, no major business adjustments, and no major changes in scale. The purpose of company incentives is to maintain a stable situation and retain core talents. Therefore, restricted stocks and stock appreciation rights that focus on long-term development and earnings are more appropriate.

During the recession of the company, the profitability of the company is declining and its survival is threatened. [7] The long-term development is not optimistic, and employees cannot predict the future development and benefits of the company. Therefore, at this stage, it is not appropriate to adopt a medium- and long-term incentive method in which the benefits are realized in the future.

\section{2) Clarify the Company's Competitive Strategy}

According to Porter's competition theory, the company's competitive strategy is divided into costleading strategy, differentiation strategy and centralization strategy. Companies adopting different competitive strategies have differences in strategic goals, development paths, and core advantages, and their incentive target groups and goals are naturally different.

Companies that adopt cost-leading strategies must establish efficient and large-scale production facilities, strictly control the costs of management, research and development, services, advertising, etc., and maintain their competitive advantages by continuously reducing costs.[8] Companies that adopt this competitive strategy do not have a high demand for motivating employees and retaining and restraining employees. Its main strategy is to reduce labor costs and minimize expenditure on salary incentives. Therefore, stock options do not require additional costs for the company and are funded by the incentive objects themselves, but relatively weakly binding incentive methods are more appropriate.

Companies that adopt a differentiation strategy emphasize uniqueness, and strive to provide customers with products, services, and brand images that are unique in the industry and that are different from other companies in order to maintain their special position in the industry. [9] Companies that adopt this competitive strategy pay much attention to the creativity of employees and their ability to bring benefits to the company in the long run. The demand for stimulating the vitality and creativity of employees and maintaining the core $R \& D$ team is more prominent. Therefore, restricted stocks that allow core employees to participate in corporate management and whose incentive income can only be obtained through long-term performance are more suitable.

Companies that adopt a centralized strategy pay more attention to market segmentation, focusing on a particular customer group, a segment of a product line, or a regional market.[10] It achieves differentiation by meeting the needs of special objects, or achieves low cost when serving this object, or both can improve its own profitability. Companies that adopt this competitive strategy pay the most attention to customer satisfaction indicators, so any individual and behavior that can contribute to improving customer satisfaction should be rewarded. And companies that adopt this strategy have the characteristics of both costing and differentiated strategies. They must pay attention to the incentive and retention of core personnel and cost control. Therefore, companies can appropriately expand the scope of incentive objects, comprehensively adopt stock options, restricted stocks, stock appreciation rights and other methods to adopt targeted incentives or combined incentives for different target groups. Carry out medium and long-term incentives in different categories and levels to meet the needs of different employee groups.

\section{3) Clarify the company's incentives}

According to relevant policy requirements for equity incentives of state-controlled listed companies, the main targets of equity incentives are directors, senior managers, and core technical personnel and management backbones who have a direct impact on the overall performance and sustainable development of listed companies. The above categories of personnel have different roles and contributions to the enterprise, their respective needs, and personnel characteristics are also different. Therefore, the medium and long-term incentive methods adopted should also have their own focus.[11]

According to the relevant provisions of the "Company Law of the People's Republic of China", a director refers to a person who is democratically elected by the company's shareholders (large) meeting or employees who has actual power and authority to manage company affairs. It is the main force of the company's internal governance and internal management Corporate affairs, external economic activities on behalf of the company. It can be seen that directors are important management personnel of the company, and they have the right to make 
decisions about the company's strategy, development direction, and major issues.[12] It is also a key concern that the company needs to evade the pursuit of personal short-term interests and ignore the company's long-term development interests. Therefore, when implementing medium- and long-term incentives for company directors, a long-term, incentive- and restraint-oriented approach should be adopted. That is to say, it is necessary to pay attention to giving it certain management power and economic incentives, so that it can participate in the company's management decision-making and share the company's development dividends as the owner of the company to a certain extent. Therefore, restricted stocks, which have a long liquidation cycle and strong binding force, are more suitable.

Senior managers are generally responsible for the specific implementation of the company's shareholders' meeting or board of directors' relevant requirements, and the implementation of major company decisions. Their main task is to decompose the higher-level requirements to the ground, and their decision-making power is relatively weak. Most of them have certain pursuits and desires to truly participate directly in the company, and such personnel are also one of the key core talents that the company needs to retain. Therefore, in the selection of incentive methods, a moderate cycle, equal emphasis on incentives and constraints, and incentives should be adopted. While motivating and retaining talents, it stimulates the enthusiasm of employees by sharing risks with the company. In terms of incentive methods, you can choose stock options with stronger incentives based on the characteristics of business development and personnel conditions. Although this kind of incentive method is less binding, the risk is relatively low, and it also avoids the lack of incentive effects for senior managers to participate in the company's decision-making prematurely.[13]

Core technical personnel and management backbone are the key core talents that the company needs to retain for a long time. But they are at a relatively low level in the company, and their position in the company is to engage in specific management or technical work. They are generally not suitable for participating in the company's operation and management, nor are they suitable for having too much decision-making authority.[14] In the choice of incentive methods, they are more suitable for medium and long-term incentive methods with short periods and mainly incentives. Therefore, stock appreciation rights that only enjoy value-added rights, do not have shareholder rights, and have a short realization period are more appropriate.

\section{Conclusion}

When selecting incentive methods, state-controlled listed companies can take the development stage of the company, the competitive strategy adopted, and the main incentive objects as a reference.

Commonly used medium and long-term incentives for state-controlled listed companies include stock options, restricted stocks and stock appreciation rights. The difference between these three methods is mainly reflected in the enjoyment of rights and binding force.
Among them, the incentive objects of restricted stocks enjoy the largest rights, bear the highest risks, and have the strongest binding force, followed by stock options, and stock appreciation rights the weakest.

When an enterprise chooses an incentive method, it can first conduct a comprehensive analysis of the development stage of the enterprise, the competitive strategy adopted, and the main incentive objects.

From the perspective of the development stage of the enterprise: It is more appropriate for companies in the early stage to choose stock options and restricted stocks. Companies in the growth stage are more suitable for stock option incentives. Companies in the stable period often choose restricted stocks and stock appreciation rights. Companies in a recession period are generally not suitable for medium and long-term incentives.

From the perspective of corporate competitive strategy: Companies that adopt cost leadership strategies are suitable for stock option incentives. Companies adopting differentiated strategies are suitable for choosing restricted stocks. Companies that adopt a centralized strategy should use stock options, restricted stocks, stock appreciation rights and other methods to adopt targeted incentives or combined incentives for different target groups.

From the perspective of the company's incentive targets: directors are suitable to adopt restricted stocks. Senior managers are suitable for using stock options. Core technical personnel and management backbones are more suitable for using stock appreciation rights.

\section{Acknowledgment}

This project is supported by the State Grid Corporation of China Technology Project "Research on Talent Supply and Demand Analysis Model and Supply Strategy Research Adapting to Company Strategy" (SGSC0000KXJS2000095).

\section{REFERENCES}

1. Jin, Z., "Research on the Medium and Long-term Incentive Mode of State-owned Enterprises," in Modern Economic Information, vol.12, Beijing, 2017, pp. 70.

2. Ma, X., "Enterprise Short-term Incentive and Mid- and Longterm Incentive Compensation Plan Design," in China Labor, vol.21, Beijing, 2016, pp. 49-52.

3. Wang, D., "Research on Medium and Long-term Incentives of State-owned Enterprises," in Military and civilian dual-use technology and products, vol.21, Beijing, 2015, pp. 57-62+65.

4. Deng, L., "Discussion on Long-term Incentives in Enterprises," in Human Resource Management, vol. 10, Beijing , 2013, pp. 173.

5. Li, Y., "Research on the Establishment of Medium and Longterm Incentive Mechanism for State-owned Enterprises," in Modern Business, vol. 22, Beijing, 2017, pp. 129-130.

6. Fang, Z., "Analysis on the Optimization of the Design of the Equity Incentive Contract of Listed Companies," in Finance and Accounting Communications, vol. 20, Beijing , 2020, pp. 112$115+124$.

7. Zhao, Q., "Research on the Distribution Characteristics and Dynamic Trends of Equity Incentives of Listed Companies in 
China," in Human Resources Development, vol. 18, Beijing , 2020, pp. 95-96.

8. Guan, X., "Research on Incentives Based on Senior Managers," in Modern Marketing (Business Edition), vol. 9, Beijing , 2020, pp. 4-5.

9. Wang, R., "Analysis of the Influencing Factors of the Effectiveness of the Equity Incentives of Listed Companies," in China Management Information Technology, vol. 23, Beijing , 2020, pp. 56-57.

10. Li, L., "Research on the Equity Incentive System of Huawei Company," in China Management Information Technology, vol. 23, Beijing , 2020, pp. 60-61.
11. Zheng, J., "Implementation Mode and Optimization of Equity Incentive System," in Times Economics and Trade, vol. 23, Beijing, 2020, pp. 16-18.

12. Sun, Q., "The Influence of Equity Incentive System on Enterprise Development," in Cooperative Economy and Technology, vol. 16, Beijing, 2020, pp. 108-109.

13. Zhang, K., "Analysis of the equity incentive mechanism of enterprise managemen," in Modern Business, vol. 21, Beijing , 2020, pp. 138-139.

14. Li, D., "Research on the Choice of Equity Incentive Models of Listed Companies," in Investment and Cooperation, vol. 7, Beijing, 2020, pp. 44-46. 